\title{
Description of a new species of Pseudopaludicola Miranda-Ribeiro, 1926 from the state of São Paulo, Southeastern Brazil (Anura, Leiuperidae)
}

\author{
LUÍS FELIPE TOLEDO ${ }^{1,5}$, SÉRGIO SIQUEIRA ${ }^{2,3}$, THIAGO C. DUARTE ${ }^{2}$, \\ ANA CRISTINA P. VEIGA-MENONCELLO ${ }^{2}$, SHIRLEI M. RECCO-PIMENTEL ${ }^{2}$ \\ \& CÉLIO F. B. HADDAD ${ }^{4}$
}

${ }^{1}$ Museu de Zoologia "Prof. Adão José Cardoso", Instituto de Biologia, Universidade Estadual de Campinas, 13083-970 Campinas, São Paulo, Caixa Postal 6109. E-mail: toledolf2@yahoo.com

${ }^{2}$ Departamento de Anatomia, Biologia Celular e Fisiologia, Instituto de Biologia (IB), Universidade Estadual de Campinas (UNICAMP), 13083-863 Campinas, São Paulo,Brazil.E-mail: shirlei@unicamp.br

${ }^{3}$ Present address: Departamento de Ciências Biológicas, Universidade Estadual do Sudoeste da Bahia, (UESB), 42500-000 Jequié, Bahia, Brazil

${ }^{4}$ Departamento de Zoologia, Instituto de Biociências, Universidade Estadual Paulista Júlio de Mesquita Filho (UNESP), $13506-900$ Rio Claro, São Paulo, Brazil

${ }^{5}$ Correponding author: Luís Felipe Toledo, Museu de Zoologia "Prof. Dr. Adão José Cardoso", Instituto de Biologia, Universidade Estadual de Campinas, 13083-863 Campinas, São Paulo, Brazil, Caixa Postal 6109. E-mail: toledolf2@yahoo.com

\begin{abstract}
We describe here a new species of Pseudopaludicola ( $P$. murundu sp. nov.) that is found in the central portion of the state of São Paulo, Brazil. This new species is related to $P$. saltica, from which it distinguishes by the presence of a single, dark, and subgular vocal sac with dark longitudinal folds in males, immaculate to light brown nuptial pads in males that cover the external part of the finger I, from the wrist to the second phalanx, and 11 pairs of chromosomes without heteromorphic sex chromosomes. From all other species of the genus it distinguishes by presenting very long hindlimbs, with tibio-tarsal articulation reaching beyond the end of the snout, and absence of T-shaped terminal phalanges. Tadpoles, advertisement call, and the karyotype are described as well.
\end{abstract}

Key words: Amphibia, Pseudopaludicola, new species, tadpole, advertisement call, karyotype

\section{Resumo}

No presente estudo é descrita uma nova species de Pseudopaludicola ( $P$. murundu), encontrada no interior do estado de São Paulo, Brasil. Esta nova espécie é relacionada com $P$. saltica, da qual se distingue por possuir saco vocal subgular simples, escuro e com pregas longitudinais nos machos, calos sexuais de imaculados a marrom claro nos machos, os quais cobrem a porção externa do dedo I, do pulso até a segunda falange, e pela presença de 11 pares de cromossomos sem cromossomos sexuais heteromórficos. Das demais espécies do gênero se distingue por possuir pernas proporcionalmente mais longas, com a articulação tíbio-tarsial ultrapassando o focinho e pela ausência de falanges terminais em forma de T. Os girinos, canto de anúncio e cariótipo também são descritos.

Palavras chave: Amphibia, Pseudopaludicola, descrição de espécies, girino, canto de anúncio, cariótipo

\section{Introduction}

In the genus Pseudopaludicola Miranda-Ribeiro, 1926 twelve valid species are currently recognised (Frost 2009). These species are always small, with snout-vent lengths generally not exceeding $20 \mathrm{~mm}$, and, with few exceptions, reproducing in slow-flowing clean water in open areas, where the species lay clutches containing 